\title{
KETERKAITAN INDIKATOR MONETER SYARIAH TERHADAP PENDAPATAN DOMESTIK BRUTO
}

\author{
Yunie Fitriani, Roikhan M Aziz, Fitri Amalia \\ Masyarakat Ekonomi Syariah \\ yuni.ftri@yahoo.co.id, roikhan@gmail.com, fitri.amalia@uinjkt.ac.id
}

\begin{abstract}
The purpose of this research is to analyze in the short term and long term between the four independent variables including: the financing of Islamic banking, the Jakarta Islamic Index (JII), the Islamic Bank Indonesia certificates (SBIS), and the money supply (JUB) to gross domestic product (GDP). This research uses the test to notice any indications of Granger was awarded a long-term relationship and Error Correction Model to see the existence of a short-term relationship. The result shows that in the short-run only SBIS that have a short-run relationship to GDP. In the longrun all the independent variables can explain the long-run relationship to GDP
\end{abstract}

Keywords: Islamic Monetary Instruments; GDP; Error Correction Model

\begin{abstract}
Abstrak
Tujuan dari penelitian ini adalah untuk menganalisis hubungan jangka pendek dan jangka panjang antara pembiayaan bank syariah, Jakarta Islamic Index (JII), Sertifikat Bank Indonesia Syariah (SBIS), dan jumlah uang beredar terhadap pendapatan domestik bruto (PDB). Teknik analisis yang dipergunakan dalam mengukur hubungan jangka pendek dan jangka panjang adalah dengan menggunakan model koreksi kesalahan (ECM). Hasil yang ada menunjukkan bahwa dalam jangka pendek hanya SBIS yang memiliki pengaruh terhadap PDB. Sedangkan dalam jangka panjang seluruh variabel bebas memiliki pengaruh terhadap PDB.
\end{abstract}

Kata Kunci: Instrumen Moneter Syariah; PDB; Model Koreksi Kesalahan 


\section{PENDAHULUAN}

Perekonomian dalam pandangan Islam merupakan suatu bentuk kegiatan yang bersifat aktif. Islam sangat melarang penimbunan harta dan uang. Sebab hal ini dapat menimbulkan masalah sosial dalam masyarakat, di mana akan timbul kesenjangan yang dapat menghambat terealisasikannya kesejahteraan hidup untuk seluruh manusia. Salah satu tujuan yang hendak dicapai dalam sistem ekonomi Islami antara lain adalah terwujudnya persamaan martabat di antara umat manusia sehingga di sini perlu ditegakkan keadilan terutama dalam distribusi pendapatan.

Secara makro, tujuan ini mengarah pada terwujudnya negeri yang sejahtera (yang mampu mewujudkan kehidupan masyarakat yang adil dan makmur). Cita-cita kegiatan ekonomi menurut Islam adalah merealisasikan kekayaan, kesejahteraan hidup, dan keuntungan umum bagi seluruh masyarakat disertai niat melaksanakan hak khilafat dan diridhai Allah Swt. (baldatun toyyibatun wa rabbun ghafuur).

Islam mengatur kehidupan perekonomian dengan apa yang dimiliki dan ditunjukkan oleh Al-Qur'an dan As-Sunah dan merupakan bangunan perekonomian yang didirikan atas landasan dan dasar-dasar yaitu tentang ketelitian cara berpikir yang terdiri dari nilai-nilai Islam dan nilai-nilai ilmu ekonomi Islami (muamalah). Satrio (2005) di antara dasar-dasar tersebut adalah: terbebas dari unsur riba, unsur spekulasi/untung-untungan (gharar), unsur judi (maysir), unsur haram, serta unsur syubhat.

Pemerintah di bidang perekonomian memberi kekuasaan kepada bank sentral (BI) untuk mengatur dan mengawasi kegiatan-kegiatan (pembiayaan perbankan, SBI/SBIS) pada lembaga-lembaga keuangan. Muamalah di Indonesia diawali dengan lahirnya reksadana syariah yang diprakarsai dana reksa. Selanjutnya, PT. Bursa Efek Jakarta (BEJ sekarang BEI) bersama dengan PT. Dana Reksa Investment Management (DIM) pada tanggal 3 Juli 2000 meluncurkan Jakarta Islamic Index (JII) yang mencakup 30 jenis saham dari emiten-emiten yang kegiatan usahanya memenuhi ketentuan tentang hukum syariah (Abdul Hamid, 2009: 39). Penentuan kriteria dari komponen JII tersebut disusun berdasarkan persetujuan dari Dewan Pengawas Syariah DIM. Muamalah di bidang investasi memberii pengaruh pada jumlah uang 
yang beredar di masyarakat. Jumlah uang beredar di masyarakat bila dimanfaatkan secara bijak dengan memperhatikan perkembangan sektor finansial serta kegiatan sektor riil, akan memberi nilai positif pada peningkatan ekonomi negara (PDB).

\section{METODE}

Penelitian ini merupakan penelitian kuantitatif, yang menggunakan data runtun waktu (time series) yaitu: PDB, pembiayaan perbankan syariah, Jakarta Islamic Index, Sertifikat Bank Indonesia Syariah, dan JUB per tiga bulan (kuartalan) dari Maret 2003 sampai dengan Desember 2010. Metode yang digunakan adalah metode penelitian Historis yang bersifat KausalDistributif, artinya penelitian yang dilakukan untuk menganalisis suatu keadaan yang telah lalu dan menunjukkan arah hubungan antar variabel.

Pada penelitian ini, yang menjadi populasi adalah Produk Domestik Bruto, Pembiayaan Perbankan Syariah, Jakarta Islamic Index, Sertifikat Bank Indonesia Syariah, Jumlah uang Beredar. Sedangkan sampel yang digunakan dalam penelitian ini adalah Produk Domestik Bruto, Pembiayaan Perbankan Syariah, Jakarta Islamic Index, Sertifikat Bank Indonesia Syariah, Jumlah Uang Beredar selama periode Maret 2003-Desember 2010 dengan berupa data per tiga bulan (kuartalan). Dalam penelitian ini data yang digunakan adalah data natural log (In) dari variabel-variabel tersebut, yang berguna untuk memecahkan persamaan yang tidak diketahuinya merupakan pangkat dari variabel lain. Maka dalam penelitian ini dilakukan beberapa tahapan sebagai berikut: Uji Akar Unit, Uji Derajat Integrasi, Uji Kointegrasi, Uji Asumsi Klasik (Uji Normalitas Data, Uji Autokorelasi, Uji Heteroskedastisitas, dan Uji Linearitas)

\section{Uji Error Corection Model (ECM)}

Model yang memasukkan penyesuaian untuk malakukan koreksi bagi ketidakseimbangan disebut sebagai model koreksi kesalahan (Error Correction Model =ECM). Pengujian ECM dalam penelitian ini adalah sebagai berikut: 
Model Dasar $\quad:$ PDB $=f(P P S$, PPS, JII, JUB $)$

Model Ekonometrika $\quad:$ PDB $=\beta 0+\beta_{1} P P S+\beta_{2} \mathrm{JII}+\beta_{3} \mathrm{SBIS}+$ $\beta_{4} \mathrm{JUB}+e \ldots$ (2)

\section{Uji Error Corection Term (ECT)}

ECT adalah bagian dari pengujian analisa dinamis yaitu ECM. Nilai ECT diperoleh dari penjumlahan variabel independen tahun sebelumnya dikurangi variabel dependen tahun sebelumnya. Hal ini dimaksudkan untuk melihat bagaimana pengaruh dari model tersebut baik dalam jangka pendek maupun jangka panjang.

Model ECT yang terbentuk pada penelitian ini adalah:

$\mathrm{ECT}=$ LNPDB-LNPPS-LNJII-LNSBIS-LNJUB

\section{HASIL DAN PEMBAHASAN}

Tahap awal dalam proses pengujian yang dilakukan adalah uji stasioneritas terhadap seluruh variabel yang diuji. Dari data yang diuji, semua variabel stasioner pada second difference. Hal ini dapat dibuktikan dengan Nilai Phillips-Perron test lebih besar dari Mac.Kinnon Critical Value 5\% (PPtest > CV 5\%). Kesimpulan dari data yang diolah adalah Ho ditolak yaitu semua variabel sudah stasioner pada tingkat second difference, sehingga pengujian dapat dilanjutkan dengan uji berikutnya yaitu Uji Kointegrasi.

Pendekatan Kointegrasi merupakan isu statistik yang tidak dapat diabaikan yang berkaitan erat dengan pengujian terhadap kemungkinan adanya hubungan keseimbangan jangka panjang antara variabel-variabel ekonomi seperti yang dikehendaki teori ekonomi. Dari hasil Uji Kointegrasi di dapat bahwa semua variabel stasioner pada ordo yang sama, yaitu pada II (2) atau second differeence. Hasil uji kointegrasi menunjukkan nilai PP tes > CV $5 \%$ yaitu $-8.871448>-1.952066$ dengan probabilitas 0.0000 sehingga $\mathrm{Ho}$ ditolak. Artinya residual dari persamaan telah stasioner pada derajat integrasi nol atau II(0). Sehingga setiap variabel dikatakan terkointegrasi atau terdapat adanya indikasi hubungan dalam jangka panjang.

Berdasarkan output data diolah hasil regresi ECM di dapat hasil sebagai berikut: 


$$
\begin{aligned}
& \mathrm{D}(\text { LNPDB })=9.428204+0.015109^{*} \mathrm{D}(\text { LNPPS })+0.044817^{*} \mathrm{D}(\text { LJII })- \\
& 0.025095^{*} \mathrm{D}(\text { LNSBIS })+0.259568^{*} \mathrm{D}(\text { LNJUB }) \\
& 0.248913^{*} \operatorname{LNPPS}(-1) \quad-1.203843^{*} \quad \text { LNJII(-1) - } \\
& 1.277538^{*} \operatorname{LNSBIS}(-1) \quad-0.758809^{*} \operatorname{LNJUB}(-1) \quad+ \\
& 1.245745^{\star} \mathrm{ECT}
\end{aligned}
$$

Keterangan:

$\mathrm{D}($ LNPDB $)=$ Perubahan Indeks PDB periode $\mathrm{t}$

$\mathrm{D}($ LNPPS) = Perubahan Pembiayaan Perbankan Syariah periode $\mathrm{t}$

$\mathrm{D}(\mathrm{LNJII}) \quad=$ Perubahan Jakarta Islamic Index periode $\mathrm{t}$

$\mathrm{D}($ LNSBIS) $=$ Perubahan Sertifikat Bank Indonesia Syariah periode $\mathrm{t}$

$\mathrm{D}($ LNJUB $) \quad=$ Perubahan Jumlah Uang Beredar periode $\mathrm{t}$

LNPPS $(-1) \quad=$ Pembiayaan Perbankan Syariah $\mathrm{t}-1$

LNJII(-1) = Jakarta Islamic Index $\mathrm{t}-1$

LNSBIS $(-1)=$ Sertifikat Bank Indonesia Syariah $\mathrm{t}_{\mathrm{t}-1}$

LNJUB $(-1) \quad=$ Jumlah Uang Beredar $\mathrm{t}-1$

Pada Jangka Pendek hasil pengujian membawa implikasi bahwa tidak terdapat hubungan jangka pendek antara variabel PPS dan PDB. Sedangkan pada jangka panjang terdapat hubungan antara variabel pps dan PDB. Pada Jangka Pendek dalam pengujian ini memberikan penjelasan bahwa tidak terdapat hubungan jangka pendek antara variabel JII dan PDB. Pada Jangka Panjang terdapat hubungan jangka panjang antara variabel JII dengan PDB.

Pada Jangka Pendek dalam pengujian ini memberikan penjelasan di mana variabel SBIS memberikan pengaruh terhadap PDB. Dalam penelitian ini terdapat implikasi bahwa terdapat hubungan dalam jangka panjang antara variabel SBIS dan PDB. Pada Jangka Pendek tidak terdapat hubungan jangka pendek antara variabel JUB dengan variabel PDB. Pada jangka panjang dalam pengujian ini memberikan penjelasan di mana variabel JUB memberikan pengaruh terhadap PDB.

Jumlah Uang beredar dalam masyarakat hendaknya dimanfaatkan secara proporsional antara sektor keuangan dan sektor riil, yang nantinya akan mempengaruhi tumbuhnya perekonomian negara. Uang yang ada di masyarakat bila hanya di investasikan pada sektor keuangan tanpa diimbangi 
dengan berinvestasi di sektor riil, maka jumlah output yang dihasilkan di suatu negara akan berkurang. Modal yang terkumpul dalam pasar modal, khususnya pasar modal syariah pada gilirannya akan mengalokasikan dana yang bertambah pada perusahaan yang produktif (menghindari uang iddle) yang mampu menambah kapasitas produksi, menambah barang dan jasa dan memperluas lapangan kerja. Beberapa implikasi dan saran yang ditujukan bagi para pelaku ekonomi, baik pihak swasta, perbankan maupun pemerintah dalam menjalankan kegiatan ekonomi syariah.

Adanya indikasi hubungan antara variabel pembiayaan perbankan syariah, Jakarta Islamic Index, sertifikat Bank Indonesia syariah, dan jumlah uang beredar terhadap PDB sudah diakui oleh para ekonom beberapa periode lalu. Dapat dilihat dari berbagai penelitian empiris yang kemudian melahirkan berbagai teori ekonomi yang terdapat pada berbagai literatur.

Yulizar D. Sanrego dan Aam S. Rusydiana (2007) melakukan penelitian mengenai pertanian berkontribusi besar terhadap PDB yakni sebesar 13,8 persen (2007). Seiring dengan adanya peran strategis sektor pertanian dalam menyerap tenaga kerja, menurunkan angka kemiskinan maupun potensinya dalam menyumbang PDB negara, oleh sebab itu industri perbankan syariah Indonesia memberi peluang pembiayaan UMKM sektor pertanian.

Penelitian yang dilakukan oleh Meisya Dwi Putri (2008) menggunakan analisis deskriptif. Gross Domestic Product (GDP) negara Sudan setelah melakukan Islamisasi yaitu pada tahun 1994, rata-ratanya hamper 7 persen, di dapat dari produk nasionalnya yang mencapai US\$23,7 miliar, dan produk nasional perkapita sebanyak $\$ 870$. Kemudian, pada tahun 2008 GDP Sudan mengalami pertumbuhan sebanyak US\$36,7 miliar, dan GDP perkapitanya sebanyak US\$ 937. Variabel Pembiayaan Perbankan Syariah, dan Jakarta Islamic Index berhubungan positif terhadap pendapatan pemerintah yang pada gilirannya akan mengalokasikan dana yang bertambah pada perusahaan-perusahaan yang produktif, menambah kapasitas produksi, menambah barang dan jasa sehingga dapat memperluas lapangan kerja, jumlah uang yang beredar di masyarakat memiliki keeratan yang tinggi dalam menggerakkan perekonomian nasional, dan instrumen SBIS memiliki pengaruh yang positif dalam mengatasi masalah likuditas keuangan pada 
lembaga keuangan yang dapat mempengaruhi pertumbuhan ekonomi. Pengeluaran perbankan, swasta dan pemerintah yang meningkat akan meningkatkan pula Pendapatan Domestik Bruto (PDB) yang akan diterima oleh negara.

\section{SIMPULAN}

Dalam jangka panjang variabel pembiayaan perbankan syariah dapat digunakan untuk memprediksi nilai PDB, sedangkan dalam jangka pendek tidak terdapat pengaruh pembiayaan perbankan syariah terhadap PDB. Dalam jangka panjang variabel Jakarta Islamic Index dapat digunakan untuk memprediksi PDB, sedangkan dalam jangka pendek tidak terdapat pengaruh Jakarta Islamic Index terhadap nilai PDB.

Dalam jangka panjang dan jangka pendek variabel SBIS dapat digunakan untuk memprediksi nilai PDB. Dalam jangka pendek juga terdapat pengaruh SBIS terhadap PDB. Dalam jangka panjang terdapat pengaruh Jumlah uang Beredar (JUB) terhadap PDB, sedangkan dalam jangka pendek tidak terdapat pengaruh jumlah uang beredar (JUB) terhadap nilai PDB.

\section{PUSTAKA ACUAN}

Bley, Jorg and Kermit Kuehn. 2004. Conventional Versus Islamic Finance: Student Knowledge and Perception in the United Arab Emirates. International Journal of Islamic Financial Services Volume 5 No. 4.

D.Sanrego, Yulizar dan Aam S. Rusydiana. 2007. Peran Perbankan Syariah dalam Mendorong Agro Investasi. Jurnal Keuangan dan Perbankan, Volume 13, hal. 311-314.

Dwi Putri, Meisya. 2008. Peranan Perbankan Syariah dalam Menciptakan Stabilitas Moneter di Sudan. Skripsi Tidak Dipublikasikan. Jakarta: UIN Syarif Hidayatullah Jakarta.

Hamid, Abdul. 2009. Pasar Modal Syariah". Jakarta: Lembaga Penelitian UIN Jakarta. 
Hsing, Yu et. All. 2005. Macroeconomic Policies and Economic Growth: The Case of Costa Rica. The Journal of Applied Business Research. Volume 21, Number 2.

Huda, Nurul, dkk. 2007. Investasi pada Pasar Modal Syariah. Jakarta: Kencana.

Kahf, Monzer. 1995. Ekonomi Islam. Jakarta: Pustaka Pelajar.

Makaryanawati dan Misbachul Ulum. 2009. Pengaruh Tingkat Suku Bunga dan Tingkat Likuiditas Perusahaan terhadap Resiko Investasi Saham yangTerdaftar pada Jakarta Islamic Index. Skripsi Tidak Dipublikasikan. Malang: Universitas Negeri Malang.

Mankiw, N. Gregory. 2007. Makro Ekonomi. Jakarta: Erlangga.

Manurung, Mandala, dkk. 2004. Uang, Perbankan, dan Ekonomi Moneter". Jakarta: FEUI.

Mishra, PK and US Mishra. 2010. Money, Price, and Output: A Causality test for India". Euro Journals Publishing.

Muhammad. 2005. Manajemen Dana Bank Syariah". Jakarta: Ekonisia.

Rodoni, Ahmad. 2009. Investasi Syariah. Jakarta: Lembaga Penelitian UIN Syarif Hidayatullah Jakarta.

Ulfa, Almizatun. 2003. Indonesia Satu dan Stabilitas Kurs Rupiah: Analisis Stabilitas Exchange Rate Indonesia Pasca Krisis 1997. Jurnal Keuangan dan Moneter, Volume 6 No. 2.

Wirdyaningsih, Karnaen Perwatatmadja, dkk. 2005. Bank dan Asuransi Islam di Indonesia". Jakarta: Kencana. 